\title{
The Use of Liquidating Trusts to Obtain the Benefits of Section 337 of the Internal Revenue Code of 1954
}

The use of liquidating trusts by corporations in order to distribute all their assets to their shareholders is not new to corporate advisers. ${ }^{1}$ However, recent rulings ${ }^{2}$ by the Internal Revenue Service have introduced tax aspects to the practice by giving approval to the use of the trust device in order to meet the twelve month liquidation requirement of section 337 of the Internal Revenue Code of $1954 .^{3}$ Although the rulings come as welcome relief to the management and shareholders of liquidating corporations holding intangible assets that are impractical to distribute in kind to shareholders, the language of the rulings contains serious ambiguities concerning the extent to which the trust device will be allowed as an alternative to sale or division of corporate assets. This comment suggests that a broad and expansive use of liquidating trusts is consistent with the purposes and rationale of section 337, and, therefore, that these rulings should be interpreted liberally.

1 For a general discussion of the use of liquidating trustees to avoid the practical difficulties involved in corporate distributions of assets to shareholders, see Boley, Income-Tax Problems in the Purchase and Sale of Corporate Assets, 29 ORE. L. REv. 258 (1950); Emery, Liquidating Distributions by Corporations Preceding Sale of Assets, 27 TAXEs 1057 (1949); Katcher, Liquidation Problems and Pitfalls, N.Y.U. 17Th INsT. ON Fed. TAX 827 (1959).

2 Rev. Rul. 63-245, 1963-2 CuM. Bull. 144; Rev. Rul. 65-257, 1965-2 CuM. Bull. 89.

3 Section 337 provides in part:

(a) General Rule.- If-(1) a corporation adopts a plan of complete liquidation on or after June 22, 1954, and (2) within the 12 month period beginning on the date of adoption of such plan, all of the assets of the corporation are distributed in complete liquidation, less assets retained to meet claims, then no gain or loss shall be recognized to such corporation from the sale or exchange by it of property within such 12 month period.

The statute enables the corporation to sell all of its assets and distribute the proceeds to the shareholders with only a single shareholder tax upon redemption of the stock. The statute does not apply to collapsible corporations, corporations liquidating within one month, or corporate subsidiaries, except to the extent that the subsidiary qualifies under \$334(b)2. These statutory exceptions will not be considered in this comment. They are amply covered in Axelrad, Collapsible Corporations and Collapsible Partnerships, So. CaL. 12th Inst. on TAx Planning 269 (1960); Axelrad, Recent Developments in Collapsible Corporations, 36 TAxEs 893 (1958); DeWind and Anthoine, Collapsible Corporations, 56 Colum. L. REv. 475 (1956); Hall, The Consenting Collapsible Corporation-Section 341(f) of the Internal Revenue Code of 1954, 12 U.C.L.A.L. REv. 1365: McGaffey, The Deferral of Gain in One-Month Liquidations, 19 TAX L. Rev. 327 (1954); Corporate Liquidations Under Section 333, 18-8d Tax Managemenx Portfolto A-1 (1964). 
Section 337 requires that a corporation completely distribute all of its assets, "less assets retained to meet claims," within a twelve month period from the date it adopts a plan of liquidation ${ }^{4}$ if it wishes to avoid a corporate tax on the sale of appreciated assets. If the corporation fails to find purchasers for all assets by the termination of the liquidation period, ${ }^{5}$ its only practical course is a last-minute distribution in kind of the unsold assets to its shareholders. However, a distribution in kind poses both tax and non-tax difficulties for the distributee shareholders. The tax difficulty arises when the shareholder sells the assets, for the Internal Revenue Service may argue that these subsequent sales by the shareholder should be attributed to the corporation and that the requirements of section 337 have not been met. ${ }^{6}$

4 The Regulations provide: "Ordinarily the date of the adoption of a plan of complete liquidation is the date of adoption by the shareholders of the resolution authorizing the distribution of all the assets of the corporation (other than those retained to meet claims) in redemption of all its stock." Treas. Reg. $\$ 1.337-2(b)$ (1955). However, attempts by the taxpayers to fragment the sale, so that loss assets are sold prior to the adoption of a plan of liquidation for a deductible loss while appreciated assets are sold after, will meet with some difficulty, for the Regulations further provide: "The date of the adoption of the plan of liquidation shall be determined from all the facts and circumstances." Ibid. The corporation seeking to straddle $\S 337$ (a) may find itself ineligible to obtain the benefits of \$ 337 if more than twelve months have elapsed between the pre-dated plan and the final distribution of all its assets. However, attempts by the Service to combat the "straddle device" have not been too successful. See Bitrker and Eustice, Federal Income Taxation of Corporations and Shareholders 392-96 (2d ed. 1966); Boland, A Review of Developments Under Section 337 of the Internal Revenue Code of 1954, 42 TAxes 676 (1964). General commentary concerning the problems of determination of the date of adoption of the plan of liquidation is found in Weir, Two Tax Approaches in Disposing of Corporate Assets, 2 SANTA CLARA LAw. 1 (1962); Comment, Watch Your Step on the Way Out-Tax Savings on Sale of Corporate Assets Under Section 337, 1954 Internal Revenue Code, 24 Mo. L. Rev. 343 (1959).

Although Treas. Reg. $\$ 1.337-2$ (b) (1955) clearly states that under no circumstances can the corporation obtain an extension of the twelve month liquidation period, there has been little authority on whether the corporation can rescind the plan of liquidation, adopt a new plan later, and still have a full twelve month distribution period. For authorities supporting the legality of such rescission, see 1 RabKIn \& Johnson, FEDERAL GIFT aNd ESTATE Taxation 2376 (1961); Shaw, Working with the Revenue Code-1960, at 71 (1960). For authority disputing the validity of rescission of the plan of liquidation, see Silverstein, Section 337 and Liquidation of the Multi-Corporate Enterprise, N.Y.U. 16TH INST. ON FED. TAX 429, 434 n.17 (1958).

5 Although Treas. Reg. $\$ 1.337-2(a)$ (1955) allows prior negotiations by the corporation in advance of the plan of liquidation, the situation may arise where the closing contract fails to materialize, thus frustrating a well-planned liquidation.

6 There have been no cases on the question whether the Court Holding doctrine, see text accompanying note 11 infra, would be applicable to a case not covered by $\S 337$. However, there has been unanimous agreement among the commentators that the Court Holding decision is not a dead letter. See 1 Rabkin \& Johnson, Frderax Income, GifT and Estate TAXation \& 23.10(3) (1962); Brookes, Recent Tax Developments in Corporate Liquidations, So. Cal. 12Th Inst. ON TAX Planning 233, 248-49 (1960); McGaffey, The Rationale and Requirements of Section 337, 40 TAXES 681 (1962); Corporate Liquidations Under Section 337, Tax Management Portfolio No. 18 (1965). 
The taxpayers will then be subjected to a double tax-on the corporation and on the shareholder personally-on all sales made during liquidation. ${ }^{7}$ The non-tax problems arise when the shareholders of a widely held corporation receive indivisible and fractional interests in the corporate assets. After receipt of the assets, some of the shareholders may fail to agree on the sale of the property and thus prevent the majority from offering a readily marketable title. ${ }^{8}$ Also, effective negotiations with prospective purchasers will probably be precluded by distribution in kind to numerous and scattered shareholders. If the asset is a disputed claim, effective settlement will obviously be almost impossible. ${ }^{9}$

The tax difficulties surrounding distribution of assets not susceptible to sale or division in kind have been substantially alleviated by the two recent Internal Revenue Service rulings ${ }^{10}$ which recognize the validity for tax purposes of a transfer of corporate assets to an independent trustee selected by the shareholders. The trusteeship device makes possible a more profitable sale of assets since the trustee centralizes negotiations, eliminates title problems resulting from a division in kind, and lessens the pressure under section 337 to make a forced sale. Since the recent revenue rulings have made the liquidating trust a feasible alternative to unwieldy sale or division in kind of corporate assets, it is advisable to examine the limitations as well as the opportunities which the rulings have brought to the use of the trust device.

\section{Pre-1954 Use of Liquidating Trustees}

Section 337 was enacted primarily to eliminate the confusion surrounding the Supreme Court's attempts in Commissioner $v$. Court Holding Co., ${ }^{11}$ and United States v. Cumberland Public Service Co. ${ }^{12}$ to limit the circumstances in which a sale by the shareholders in liquidation will be attributed to the corporation, thus rendering the profit corporate income.13 Under pre-section 337 case law, a sale by the corporation followed by a distribution of the proceeds to

7 See Commissioner v. Court Holding Co., 324 U.S. 331 (1945).

8 See Boley, supra note 1, at 258.

9 See McGaffey, supra note 6, at 705 .

10 Rev. Rul. 63-245, 1963-2 Cum. BuLl. 144; Rev. Rul. 65-257, 1965-2 Cum. BuLl. 89.

11324 U.S. 331 (1945).

12338 U.S. 451 (1950).

13 S. REP. No. 1622, 83d Cong., 2d Sess. 47-48, 256, 258 (1954). Excellent statements of the problems faced by pre-section 337 tax planners are found in the following articles: Cary, The Effect of Taxation on Selling Out a Corporate Business for Cash, 45 ILL. L. REv. 423 (1950); Emery, Liquidating Distributions by Corporations Preceding Sale of Assets, 27 TAXEs 1057 (1949); Gutkin and Beck, Sale of Assets Received on Liquidation, 28 TAXES 328 (1950); Comment, The Liquidation of Corporate Ownership Interests, 14 U. CFI. L. REv. 647 (1947). 
the shareholders was given different tax treatment from a liquidation in kind to the shareholders followed by shareholder sale of the assets. ${ }^{14}$ Therefore, in order to avoid a corporate tax on liquidation, the corporation would normally negotiate with a purchaser for the sale of its assets and, when assured of a closing contract, distribute the assets in kind, whereupon the shareholders would complete negotiations and sell the assets. This avenue of tax avoidance was closed in the Court Holding decision. The Supreme Court upheld a finding that the transfer of an apartment building to shareholders was a subterfuge employed solely to take advantage of the tax law and, on the strength of that finding, attributed the sale to the corporation. The Court emphasized that the corporation had already agreed to sell the apartment building and the shareholders were thus mere "conduits" for passing title to the purchaser. Court Holding made it imperative that shareholders, acting as shareholders, conduct any preliminary negotiations for the sale of the corporation's assets. ${ }^{15}$ However, it was often impractical for the corporation to make a distribution in kind without any prospect of subsequent purchase. The shareholders would be faced with the possibility of a heavy tax imposed upon liquidation without sufficient funds to pay it, and would be forced to manage a going business or an operating asset until a purchaser could be located. ${ }^{16}$

Even if shareholders negotiated prior to actual liquidation, this procedure was not successful if the shareholders were also members of the corporate management. In this situation, courts invariably imposed a corporate tax, contending that the sale was made by an agent of the corporation, rather than an agent for the shareholders. ${ }^{17}$ The difficulty with this treatment is apparent, since the real owners of a liquidating close corporation, who normally are the directors and officers, would not be able to represent themselves in the negotiations for the sale of the corporate assets distributed to them. ${ }^{18}$ To overcome these difficulties, the shareholders have frequently appointed a trustee to represent them in the process of negotiations and sale.

14 The Court in General Utilities Co. v. Helvering, 296 U.S. 200 (1935), held that a corporation realized no gain from the distribution of a dividend in kind, on the grounds that the corporation had neither made a sale nor discharged an obligation. The holding of this case is reflected in Treas. Reg. 103, § 19.22(a)-21 (1940), which provides that "no gain or loss is realized by a corporation from the mere distribution of its assets in kind in partial or complete liquidation, however they may have appreciated in value since the acquisition."

15 See Stock, Purchase and Sale of a Corporate Business, 27 TAXEs 627 (1949).

16 See Boley, supra note 1, at 264.

17 See, e.g., Tripett v. Commissioner, 118 F.2d 764 (5th Cir. 1941); Taylor Oil \& Gas Co. v. Commissioner, 47 F.2d 108 (5th Cir.), cert. denied, 283 U.S. 862 (1931); Burnet v. Lexington Ice \& Coal Co., 62 F.2d 906 (4th Cir. 1933).

18 See Cary, supra note 13, at 423. 
The pre-1954 case law concerning the agency status of liquidating trustees was one of inconsistent and irreconcilable principles. ${ }^{19}$ However, there were several predictable factors that the courts appeared to emphasize in determining whether the trustee was an agent of the corporation or of the shareholders. Since the Regulations provided for a corporate tax on sales made by the statutory liquidators on the theory that they acted for the corporation, ${ }^{20}$ any trustee whose functions were those normally performed by the statutory trustees in dissolution was considered a corporate agent by the Revenue Service. ${ }^{21}$ In order for the trustee to be considered an agent for the shareholders, it was necessary that: (1) he not have powers to collect debts or settle the liabilities of the corporation;22 (2) the shareholders unanimously appoint the trustee; ${ }^{23}$ (3) the trust indenture expressly provide that the trustee act solely for the benefit of the shareholders in any conveyance of the assets; ${ }^{24}$ (4) the corporate management refrain from taking any part in the negotiations over the sale of the property; ${ }^{25}$ and (5) the procedure by which the trustee was appointed comply thoroughly with the state dissolution procedure. ${ }^{26}$ However, even if these formalities were met, the courts were still concerned that the liquidation be bona fide. Thus, the courts would resolve any ambiguities in the question of agency against the taxpayer, especially if there appeared to be no purpose in liquidating before sale other than tax avoidance. ${ }^{27}$

19 Compare Tazewell Electric Light \& Power Co. v. Strother, 84 F.2d 327 (4th Cir. 1936), Burnet v. Lexington Ice \& Coal Co., 62 F.2d 906 (4th Cir. 1933) and Chilhowee Mills Inc., 4 T.C. 558 (1945), rev'd on other grounds, 152 F.2d 137 (D.C. Cir. 1945) with Acampo Winery \&: Distilleries, Inc., 7 T.C. 629 (1946), Cummins Distilleries Corp. v. United States, 166 F.2d 17 (6th Cir. 1948) and Ripy Bros. Distilleries, Inc., 11 T.C. 326 (1948).

20 Treas. Reg. \& 29.22(a)-20 (1943): "When a corporation is dissolved, its affaits are usually wound up by a receiver or trustees in dissolution. The corporate existence is continued for the puxpose of liquidating the assets and paying the debts, and such receivers or trustees stand in the stead of the corporation for such purpose. . . . Any sales of property by them are to be treated as if made by the corporation for the purpose of ascertaining the gain or loss."

21 See cases cited supra note 17.

22 See Wichita Terminal Elevator Co. v. Commissioner, 162 F.2d 513 (10th Cir. 1947).

23 See Kessler, Purchase and Sale of a Closely Held Corporate Business, 28 TAXEs 1169 (1950).

24 See, e.g., Jones v. Grinell, 179 F.2d 873 (10th Cir. 1950); Acampo Winery \& Distilleries, 7 T.C. 629 (1946).

25 Compare Court Holding Co. v. Commissioner, 324 U.S. 331 (1945) and Kaufmann v. Commissioner, 175 F.2d 28 (3d Cir. 1949) with Howell Turpentine Company v. Commissioner, 162 F.2d 319 (5th Cir. 1947) and Fairfield Steamship Corp. v. Commissioner, 157 F.2d 321 (2d Cir. 1946). See also Stock, supra note 15, at 636.

26 See Hellebush v. Commissioner, 65 F.2d 902 (6th Cir. 1933).

27 See, e.g., West Coast Securities Co., 14 T.C. 947 (1950); Commissioner v. Transport Trading \& Terminal Co., 176 F.2d 570 (2d Cir. 1947); Wichita Terminal Elevator Co. v. Commissioner, 162 F.2d 513 (10th Gir. 1947); Meurer Steel Barrel Co. v. Commissioner, 144 F.2d 282 (3d Cir.), cert. denied, 324 U.S. 860 (1945). 
The decision in United States v. Cumberland Public Service Co. was hailed by many commentators as injecting an element of rationality into the treatment of distributions in kind followed by sales by the shareholder distributees. ${ }^{28}$ The facts of the Cumberland case were similar to those of Court Holding, ${ }^{29}$ but the Supreme Court in Cumberland affirmed the Court of Claims' decision that the sale was made by the stockholders. It appeared that the Court was less concerned with the form of the transaction than with the genuineness of the liquidation; thus, the tax avoidance motive no longer was considered relevant as long. as the corporation attempted a genuine distribution of its assets. However, instead of clarifying the circumstances in which a sale by the shareholders would be attributed to the corporation, the Cumberland decision actually increased the confusion; since it was not clear whether the Court had simply refused to vary the findings of the trial court as to who made the sale, or had established criteria by which a corporation could liquidate and avoid being taxed on any gains resulting from the sale of its appreciated assets. ${ }^{30}$

\section{Use of Liquidating Trusts Under the 1954 Code}

Section 337 eliminated some but not all of the tax uncertainties involved in corporate liquidations. ${ }^{31}$ One of the major problems still confronting the liquidating corporation is the difficulty of distributing assets that are essentially impractical to distribute. The liquidating trust device has been approved by the Internal Revenue Service ${ }^{32}$ as a valid means of solving this problem. However, the Service has not defined the extent to which the trust device may be used to achieve complete liquidation. Resolution of this question is important for two rea-

28 See Gutkin and Beck, supra note 13, at 332; Kessler, supra note 23, at 1169.

29 See Gelberg, The Court Holding-Cumberland Situation: Liquidation as an Incident to the Sale of Assets, N.Y.U. 13TH INST. ON FrD. TAX 605, at 607 (1955). In Cumberland, the company, not able to compete successfully with a TVA cooperative, offered to sell its stock to the cooperative, which refused. The shareholders then offered to sell the cooperative the assets, which offer was accepted. The corporation then transferred the equipment to the shareholders in partial dissolution, whereupon they consummated the sale. The Court attempted to distinguish the Court Holding decision upon the facts that there the parties had already reached an agreement which they attempted to call off; the terms of the eventual sale were the same as that negotiated; and earnest money was applied against the eventual purchase price. The Court surprisingly did not mention the fact that the directors of the petitioning corporation in the Cumberland case were the negotiators who concluded the sale, a factor which ordinarily has led courts to conclude that the sale was in fact a corporate one. See text accompanying note 25 supra. See also McGaffey, supra note 6 , at 682 .

30 See Comment, supra note 4, 24 Mo. L. REv. 343 (1959).

31 See authorities cited note 4 supra.

32 Rev. Rul. 63-245, 1963-2 Cum. Bulc. 144. 
sons. First, since the Court Holding and Cumberland decisions are still applicable, a corporation that fails to sell its assets within the twelve month liquidation period required by section 337 but which transfers its assets to the trustee in dissolution will want to show that a sale by that trustee does not fall within the Court Holding principle. Second, a failure to draft the trust instrument properly with respect to the powers of the trustee and the type of assets which can be transferred might allow the Internal Revenue Service to contend that there has not been the equivalent of a distribution to the shareholders.

Revenue Ruling 63-245 was the first published ruling allowing use of the liquidating trust device to cope with the problem of distributing to the shareholders assets that are impractical to distribute in kind. The ruling dealt with a corporation that had distributed all its assets within the twelve month liquidation period except for a claim for refund of federal taxes. Since this type of claim is not readily susceptible either to sale or division, ${ }^{33}$ the corporation transferred the claim to an . independent trustee for the benefit of the shareholders; the trustee was empowered to prosecute and collect the claim for all the shareholders. The Service held that:

[D]istribution in complete liquidation is not prevented by the existence of an asset, such as tax refund claims, which are not readily susceptible to sale or distribution among the shareholders within the 12 month period, if the corporation divests itself of the asset during such, in a manner equivalent to a distribution of the asset to the stockholder. ${ }^{34}$

This ruling represents a change in the apparent policy of the Service in that it allows the use for tax purposes of the trusteeship device without the unanimous approval of the shareholders. In the past it appeared to be the policy of the Service that if unanimous consent of the shareholders was not obtainable, it was necessary for the corporation to petition a court of competent jurisdiction for the appointment of a liquidating trustee. ${ }^{35}$ Under the new ruling, however, the number necessary to validate the appointment of a trustee in dissolution is only that which is required under state law to approve the plan of liquidation, which may be as low as two-thirds of the shareholders. ${ }^{36}$

Although Revenue Ruling 63-245 adds a certain flexibility to section

3335 Stat. 411 (1908), as amended, 31 U.S.C. § 203 (1952); Rev. Rul. 56-3, 1956-1 CuM. BULL. 685.

34 Rev. Rul. 63-245, 1963-2 CuM. Bull. 144.

35 See Letter Ruling issued to Consolidated Coppermines Corp., March 17, 1959, and October 2, 1959, reported in 1959 P-H FED. TAX SERV. II 55,164-65.

30 See Del. Code ANN. tit. 8, \& 275(c) (1953). 
337's liquidation requirements, the emphasis in the ruling on the type of assets that may be transferred to a trustee, those "not readily susceptible to sale or distribution in kind," may prove to be a severe limitation on the use of the trust device. For example, suppose the asset transferred to a trustee in dissolution is an apartment building. Can it be said that real property is not readily salable or divisible in kind? Where sale negotiations have advanced to the closing stage, but the closing is delayed either because of title problems or because the purchaser is attempting to use the pressure of time to improve his bargaining position, ${ }^{37}$ it seems that the Service could not properly contend that the property was readily salable. Nevertheless, the Service might argue that an apartment building is intrinsically a readily salable item, and thereby exclude assets such as real property from being transferred to a trustee in dissolution.

The question whether an asset such as an apartment building is susceptible to division in kind is not as uncertain. If the shareholder distributees are numerous, forcing the shareholder to accept a fractional interest in an asset in order to avoid the imposition of a corporate tax may be so inequitable as to enable the small shareholder to enjoin the plan of liquidation. ${ }^{38}$ Furthermore, distribution in kind may cause the distributees title and recording problems that can be especially cumbersome if any stock is held by a minor or by the estate of an incompetent person or a decedent, or if any shareholder dies between the time an undivided interest in the asset vests in him and the time the proposed sale is completed. ${ }^{39}$ Where there are numerous and scattered shareholders, it will be impossible to execute an instrument which will appoint an agent to represent them in any negotiations, and a distribution of assets to a portion of the shareholders may

37 Since the corporation is unable to close a contract until the plan of liquidation has been adopted by the shareholders, this tactic may be resorted to by an unscrupulous purchaser. To avoid this possibility, the corporation should take the following steps: (1) delay adoption of the plan of liquidation as long as possible; (2) provide in the contract of sale for liquidating damages in the event the closing is delayed; (3) provide in the plan of liquidation that any assets which remain unsold after a date near the closing of the twelve month period should be transferred to a trustee for the benefit of the shareholders. See Corporate Liquidations Under Section 337, 18-3d TAX MANAGEMENT PoRTrolro A-1, A-3 (1963).

38 Shrage v. Bridgeport Oil Co., 31 Del. Ch. 305, 71 A.2d 882 (1950). The Court in the Shrage case enjoined the plan of liquidation because of its unfairness to small shareholders in its provisions for distribution in kind of small interests in producing and non-producing oil and gas leases. The numerous problems of bookkeeping and taxes involved in owning small interests in many properties and the likelihood that the shareholder would not exercise any substantial supervision over so many scattered interests were emphasized by the court to show the inequities created by the plan.

39 See Boley, supra note 1, at 263. 
so becloud the title that the prospective sale cannot be consummated. The liquidating corporation facing the prospect of an unwieldy division in kind may be forced, therefore, to make uneconomic sales in order to obtain the benefits of section 337 .

These considerations suggest that the I.R.S. should not limit the assets which can be assigned to the trustee to those not readily susceptible of sale or division in kind. Since Revenue Ruling 63-245 implicitly recognizes that the transfer of assets to an independent trustee appointed by the shareholders is equivalent to a distribution to the shareholders, the agency question cannot depend on the type of assets involved. Moreover, the rationale of section 337 and the twelve month liquidation requirement will not be defeated by recognizing the trust as a workable device for transfer of a broader range of assets. The purpose of the twelve month requirement is two-fold: first, to "assure taxation of the shareholders on the full appreciation in their stock"; 40 second, to prevent the corporation from making a tax-free sale, retaining the proceeds for purposes of investment, and conducting business activities under the guise of a long range liquidation. ${ }^{41}$ However, when a corporation has transferred all of its remaining assets to an independent trustee, whether these assets are contingent claims or real property, there can be no valid contention that the company is managing a subterfuge investment, for the business entity has ceased to exist. The only issue is whether the trust itself will carry on a going business and thus defeat Congress' attempt to provide an absolute twelve month cut-off point and thereby prevent the Internal Revenue Service from having to undertake a case by case determination as to whether there has been a bona fide liquidation. Admittedly, the Service will have to scrutinize the activities of the trustee; but this policing will be relatively easy compared to supervision of the corporation itself. While a liquidating corporation maintains its trade name and administrative production structure, the special 337 trust would be hard-pressed to continue business operations secretly-the types of employment and activities of personnel would be an indication that the trust was more than a mere holding entity. Moreover, inability to continue using a trade name, as well as elimination of limited liability for torts committed by employees, is a barrier to continuation of the business behind a trust facade. In addition, the practice of some post-liquidation scrutiny is not new to the Service-the same problem arises whenever the corporation distributes its assets in kind and the distributees form a partnership.

40 See McGaffey, supra note 6, at 701.

41 See Mountain Water Co. of La Crescenta, 35 T.C. 418 (1960). 
The use of liquidating trusts under section 337 was given a broader application in 1965 by Revenue Ruling 65-257. The Ruling dealt with a corporation whose dissenting stockholders wanted their shares appraised, but whose claims could not be determined within the twelve month period required by section 337 . The Service approved the transfer by the corporation to an independent trustee of an amount of cash equal to an estimated value of the appraised shares of the dissenting shareholders plus statutory interest. The trust indenture bound the trustee to pay the minority stockholders the amount that would finally be determined by the court. If there were any remaining funds, the trustee would distribute them pro rata among the remaining shareholders. If the amount as determined by the court was more than that held by the trustee, the non-dissenting shareholders would pay the difference. The funds deposited with the trustee would in no case be returned to the corporation, nor would the corporation repay the nondissenting shareholders for any deficiency that might occur. In approving this arrangement, the Service stated that although the plan of liquidation did not specifically provide for the use of the trust device, this oversight would not defeat the tax advantages of the transfer, since the shareholders authorized the directors of the corporation to take all steps necessary to complete the liquidation of the company. This ruling represents a substantial liberalization of the pre-1954 treatment of the trustee in dissolution, since the dividing line between treatment of the trustee as agent for the shareholders rather than the corporation was then thought to be whether the agent assumed any of the liabilities of the corporation. ${ }^{42}$

Revenue Ruling 65-257 supports a more expansive use of liquidating trusts in analogous situations. An example is where minority shareholders bring a derivative suit to exert pressure on the majority in order to obtain a more favorable plan of liquidation. Since the suit might delay the corporation's attempt to liquidate completely within the twelve month requirement of section 337 , the trusteeship device can forestall this type of pressure by enabling the corporation to transfer an amount of money equal to the distributive shares of the dissenting shareholders to the trustee in dissolution. ${ }^{43}$

Under section 337 (a)2, the liquidating corporation is allowed to retain assets to meet claims and still qualify for the benefits of the nonrecognition of gain. The Regulations, interpreting this provision to

42 See cases cited note 24 supra.

43 Weissman, Use of a Trustee Suggested to Bar Minority Stockholder's Suit Killing a 337 Liquidation, $12 \mathrm{~J}$. TAxation 166 (1960). 
reach only the claims of creditors and not those of shareholders, ${ }^{44}$ further provide that such assets retained to meet claims must be specifically set aside and be reasonable in amount. ${ }^{45}$ Since the Regulations allow the corporation to set aside monies for unknown as well as known contingencies, there is always the possibility that the corporation's estimate of its unknown liabilities may be incorrect, and thus, the company will not have distributed all of its assets within the twelve month period. If the shareholders are an organized group, the difficulty may be alleviated by having the shareholders assume the liabilities. However, in many situations this may not be practical; ${ }^{46}$ as an alternative, the corporation could transfer an amount of cash to a trustee for the shareholders, who would pay off any liabilities that became due. Although the Service has not published a ruling dealing with the propriety of using a liquidating trust in this situation, there have apparently been private rulings permitting such arrangements. ${ }^{47}$

The liquidating trust can also be used effectively to avoid attribution of income to the corporation. The liquidating company which has earned income that is either subject to certain contingencies or is indeterminable in amount, and therefore has not accrued before the plan of liquidation, may transfer this claim to income as well as its other remaining assets to the shareholders. It thereby attempts to avoid tax at the corporate level and to convert what would be ordinary income

44 Treas. Reg. $\$ 1.337-2(b)$ (1955). Although $\$ 337$ refers to assets kept by the corporation to meet the claims of creditors, the Regulations refer to the retention of cash and thus imply that all assets retained to meet claims should be reduced to cash. Although this possible requirement is not warranted by the Code, the wise corporate tax planner would hesitate to allow the corporation to retain assets that may produce income. The corporate retention of income producing assets would produce an IRS contention that the amount retained was not reasonable in relation to the outstanding claims. Further, if such income is similar to the type regularly earned by the business, the corporation may be viewed as not fully liquidated, and the directors as having failed to retain assets for creditor's claims in good faith as required by the Regulations. The problem of providing for funds for creditor liabilities is amplified in Laiken, Avoiding Double Taxation on Corporate Sales and Liquidations: Section 337, N.Y.U. 16TH INST. ON FED. TAX 669, 673 (1958); MacLean, Jr., Taxation of Sales of Corporate Assets in the Course of Liquidation, 56 CoLuM. L. REv. $641,655-59$ (1956).

45 Treas. Reg. \& 1.337-2(b) (1955).

46 The problem arises mostly in publicly held corporations where, if the directors do not retain sufficient assets to meet unknown claims, they may be subject to personal liability without satisfactory means of obtaining restitution from the shareholders.

47 Ellentuck, Liquidating Trusts in Section 337 Liquidations, 52 A.B.A.J. 684, 686 (1966). Even if the Service rules that an arrangement whereby the funds are transferred to an escrowee is such as to make the escrowee a corporate agent and thus the funds are still retained by the corporation, such a transfer of corporate assets might still be helpful as evidence to the Service that a bona fide attempt has been made to dissolve the corporation and that the retention of assets was solely to meet creditor's claims. 
at the corporate level into capital gains at the shareholder level.48 In order to avoid attribution of income to the corporation, it is essential to terminate completely the existence of the corporation. ${ }^{49}$ In $J$. Ungar Inc., ${ }^{50}$ the Tax Court held that a corporation remained in existence after liquidation distributions had been made because it had retained cash to pay its liabilities. Due to this limited existence, the court held the corporation taxable for contingent earnings when they accrued. In Wood Harmon Corp. v. United States, ${ }^{51}$ the court also attributed income to the corporation after it had distributed the income right. In this case, New York condemned a parcel of a corporation's realty three days before adoption of the plan of liquidation. Within three months after adoption of the plan, the corporation sold its remaining property and distributed all its assets, including a claim against the city, to a trustee in liquidation for the shareholders. The issue was whether the corporation was still in existence when the condemnation award was determined. The lower court held that the corporation was still in existence since it retained $\$ 2500.00$ to meet its liabilities. Although the anticipatory assignment of income doctrine has not yet reached the stage where predictability of decision-making is fully possible, it appears that the fact that the corporation is no longer an entity at the time when the income accrues will carry great weight in determining whether the income is taxed at the corporate level.52 Thus, the liquidating trust will be a helpful device in avoiding any attribution of income to the corporation. Where there are numerous shareholders, it is impractical to distribute the assets to them and to have them pay a pro rata share of the corporate liabilities. However, by transferring the assets to a trustee for the shareholders, the corporation avoids attribution of income and the problems of transferee liability of a large group of stockholders.

\section{Use of the Trust Device for Missing Shareholders}

Unequivocal Service approval of the trust device has been given in at least one situation: liquidating distributions to missing shareholders. The problem of making distributions to missing shareholders has. been

48 See Kilbourn, Jr., Post-Liquidation Problems, Corporate and Individual, N.Y.U. 23D INST. ON FED. TAX 701, 702 (1965).

$49 \mathrm{Id}$. at 704 .

5026 T.C. 331 (1956), aff'd, 244 F.2d 90 (2d Cir. 1957).

51206 F. Supp. 773 (S.D.N.Y. 1962), affd, 311 F.2d 918 (2d Cir. 1963).

52 The liquidating corporation has to establish that it is no longer an entity due to its dissolution and its distribution of all its assets. However, the Service may find that the obligation of the trustee for the shareholders to pay any of the liabilities of the corporation is in itself an asset and that therefore the corporation has not, in fact, been completely dissolved. Cf. Royal Oaks Apartments Inc., 43 T.C. 243 (1964). 
met in the Regulations by a provision that a distribution to either a trustee for the shareholders, a state official, or any other person authorized by law to receive distributions for missing shareholders will be recognized as a distribution in liquidation. ${ }^{53}$ However, many states require that distributions of assets to missing shareholders be reduced to cash and deposited with a state official. ${ }^{54}$ This type of provision may cause difficulty if the corporation's only asset is an unsold piece of real property or a contingent claim. Whether the transfer of the asset to a trustee for the shareholders would satisfy these statutory provisions is a question that has never been litigated. However, there appears to be a simple solution. Although the Regulations provide that the corporation may not retain assets to meet the claims of its shareholders for redemption of its stock, it appears that there is a de minimis amount which will be allowed for this purpose. In Mountain Water Co. of La Crescenta, ${ }^{55}$ the Tax Court did not disqualify the liquidating corporation from obtaining the benefits of section 337, even though the corporation retained assets for tie holders of five shares beyond the twelve month liquidation period. The court cited its decision in Estate of Meyer, ${ }^{56}$ where the court applied a de minimis rule under the 1939 Code and allowed a retention of $5.8 \%$ of the corporate assets for shareholders who had not redeemed their shares. The emphasis in both cases on the good faith of the liquidating corporations' managers may indicate a greater flexibility in the future in allowing a greater percentage of assets to be held by the corporation for missing shareholders. ${ }^{57}$ Thus, the corporation faced with the requirement of making cash deposits for missing shareholders could transfer the assets to a trustee in dissolution for all the shareholders, and receive and retain the beneficial shares for the missing shareholders. These shares would be held by the liquidating corporation until reduced to cash, which would then be deposited with the state official.

\section{Limitations on the Use of Liquidating Trusts}

There are three major limitations mentioned by the commentators which the corporate tax planner must consider when deciding whether

53 Treas. Reg. $\$ 1.337-2(b)$ (1955). In the situation where the applicable state law makes no provision for the transfer of funds for missing shareholders, the Service, in an unpublished letter ruling, has stated that a distribution by the corporate management to a bank or similar institution of such funds will satisfy the requirements of $\S 333$. The ruling should be likewise applicable to twelve month liquidations under $\S 337$. See Mills, special 12 Month Liquidations, 14 TuL. TAX INST. 462, 472 (1965).

54 See, e.g., Ill. ANN. Stat. ch. 32, § 157.93 (Smith-Hurd 1954).

5535 T.C. 418 (1960).

56 15 T.C. 850 , rev'd on other grounds, 200 F.2d 592 (5th Cir. 1952).

57 See Boland, supra note 4 , at 687. 
to employ the liquidating trust: (1) the doctrine of classifying trusts as associations taxable as corporations; (2) the applicable state law governing the propriety of a transfer to a trustee of the corporate assets which would be binding on the non-assenting minority; and (3) the language found in the recent rulings which limits the kinds of assets which may be transferred to a trustee to those "not susceptible to sale or distribution." 58 The first limitation reflects the existence of a high degree of overlap between corporate and trust characteristics. However, the likelihood that the Internal Revenue Service will treat liquidating trusts as associations taxable as corporations appears remote in view of both the case law $^{59}$ and the regulations. ${ }^{60}$ The essential ingredients of an association taxable as a corporation are centralized management, continuity of existence, limitation of investors' liability, and transferability of shares, ${ }^{81}$ all of which can usually be found in the liquidating trust; but in order for an association to be taxed as a corporation it is also essential that the enterprise have as its main purpose the conduct of business. ${ }^{22}$ The case law insists that if the dominant purpose of the trust device is to effect a sale rather than to manage a business, the liquidating trust will not be subject to corporate income tax treatment. ${ }^{63}$ The Regulations adopted in 1960 recognized this principle:

A liquidating trust is treated as a trust for purposes of the Internal Revenue Code because it is formed with the objective of liquidating particular assets and not as an organization having as its purpose the carrying on of a profit-making busi-

58 See Ellentuck, Liquidating Trusts in Section 337 Liquidations, 52 A.B.A.J. 684 (1966); Katcher, Liquidation Problems and Pitfalls, N.Y.U. 17TH INST. ON FFD. TAX 827, 841-44 (1959); Comment, Watch Your Step on the Way Out-Tax Savings on Sale of Corporate Assets Under Section 337, 1954 Internal Revenue Code, 24 Mo. L. REv. 343, 355 (1959).

50 See, e.g., Rohmann v. United States, 275 F.2d 120 (9th Cir. 1960); Helvering v. Washburn, 99 F.2d 478 (8th Cir. 1938); Myers v. Commissioner, 89 F.2d 86 (7th Cir. 1937). Although these cases dealt with real estate investment trusts formed for the purpose of conserving and liquidating property, and not with trusts formed by former shareholders of a liquidating corporation, the anology is valid when it is recognized that the liquidating trust involves a change in the form of ownership and not a continuation of the corporate existence.

60 See text accompanying note 62 infra.

61 See Morrissey v. Commissioner, 296 U.S. 344, 359 (1935). See also 7 Mertens, Federal Income Taxation § 38A.10; Lyons, Comments on the New Regulations on Associations, 16 TAX L. REv. 441 (1961); Stephens \& Freeland, The Federal Tax Meaning of Estates and Trusts, 18 TAX L. REv. 251 (1963).

62 See Morrisey v. Commissioner, 296 U.S. 344, 360 (1935); Treas. Reg. § 301.7701-2(2) (1960). See also Driscoll, The Association Problem in Joint Ventures and Limited Partnerships, N.Y.U. 17tre INST. ON FED. TAX 1067 (1959); Hewitt, Associations Taxable as Corporations, 47 A.B.A.J. 215 (1961); Zarky, Unincorporated Organizations Taxable as Corporations, 1961 So. CaL. TAX INST. 277.

63 See cases cited note 57 supra. 
ness which normally would be conducted through business organizations classified as corporations or partnerships. However, if the liquidation is unreasonably prolonged or if the liquidation purpose becomes so obscured by business activities that the declared purpose of liquidation can be said to be lost or abandoned, the status of the organization will no longer be that of a liquidating trust. ${ }^{.4}$

A private ruling has been issued by the Internal Revenue Service stating that a proposed real estate trust for mineral royalty deposits would not be considered as an association taxable as a corporation..$^{65}$ Although this trust would have corporate characteristics, it would not have the primary objective of carrying on business; thus, it was exempted from corporate tax treatment. The trust indenture that was the subject of the private rulings limited the powers of the trustee to collection and distribution of the proceeds. In order to avoid corporate tax of the trust device, and consequent loss of the advantages of section 337 , the instrument should thus be worded so as to limit the powers of the trustee to as few management activities as reasonably possible.

The limitation imposed by state law arises from the fact that the revenue rulings permit a given percentage of shareholders to enter into a liquidating trust and provide that such action will be binding on non-assenting shareholders if the relevant state law permits such action. ${ }^{68}$ Examination of state dissolution statutes reveals that few states deal specifically with the power of a majority group of shareholders to establish a liquidating trust which would bind the dissenting shareholders. ${ }^{67}$ The typical statutory provision allows the statutory liquidators, invariably officers and directors of the corporation, power to sell, convey, and dispose of the corporate assets, discharge the corporate liabilities, and distribute the proceeds to the shareholders. ${ }^{68}$ Even under such a statute, which usually makes no specific provision for employing the liquidating trust upon dissolution, the corporation appears to have implied power to use such a device if selected by the majority of shareholders. ${ }^{69}$

64 Treas. Reg. 301.7701-4 (1960).

65 See Frehling, What Is New in Subchapter C: The Service's Current Ruling Policy, N.Y.U. 23D INST. ON FEd. TAX 421, 442 (1965).

66 Rev. Rul. 63-245, 1963-2 Cum. Bult. 144; Rev. Rul. 65-257, 1965-2 Cum. Bull. 89.

87 Ohio is one of the few states that give the liquidating corporation power to bind the minority shareholders in any corporate action aimed at dissolution. OHIO REv. CODE ANN. $\S 1701.88 \mathrm{E}$ (Baldwin 1958).

68 See, e.g., Ill. ANN. Stat. ch. 32, § 157.93 (Smith-Hurd 1954); N.J. Stat. ANN. § 14:13-5 (1939).

69 See Tazewell Electric Light \& Power Co. v. Strother, 84 F.2d 327, 329 (4th Cir. 1936). It is the opinion of Ray Garett, the principal drafter of the Model Corporation Act, 
The third major limitation on the use of liquidating trusts is the uncertainty, mentioned earlier, as to the types of assets which may be transferred to the trustee. Since the Service has been unwilling to rule publicly on whether tangible assets such as real property may be transferred to an independent trustee, it must be assumed that it has some reservations concerning the propriety of such action. There were attempts in the 86th Congress to solve the problem by amending the Internal Revenue Code to provide that:

Transfer of assets by such corporation within such 12-month period made to a liquidation trust or agency for the benefit of stockholders of the corporation shall, for the purposes of this subchapter, be treated as a distribution of the assets to such stockholders in liquidation within the meaning of this subsection and section 331 and as a transfer of the assets by such shareholders to the viust or agency, if the income of the trust or agency is currently taxable to its beneficiaries. ${ }^{70}$

Although this measure was defeated, ${ }^{71}$ it would appear important to reconsider the need for such legislation to clear up confusion over corporate use of the trust device.

\section{ConcLusion}

Section 337 has not been totally successful in solving the problems faced by liquidating corporations. The difficulty of distributing assets in kind to scattered shareholders must still be resolved. The recent revenue rulings, although helpful in their limited recognition of the trust device as an aid in corporate liquidation, create uncertainty as to their scope beyond the transfer of assets such as tax refund claims. However, in the areas of anticipatory assignment of income, retention of income to meet corporate liabilities, and full distribution of the assets in the most effective manner, an expanded use of the trust device can provide the needed flexibility to deal with the problems faced in these areas.

that the appointment by the shareholders of a trustee in dissolution in the plan of liquidation is permissible under both the Model Act and the Illinois Act. Interview in Chicago, Oct. 2, 1966. Except for Tazewell, the point had not been litigated.

As an alternative to allowing all assets to be transferred to the trustee in liquidation, the Service can impose upon the liquidating corporation the burden of showing that the transfer of assets to the trustee served a proper business purpose, and was not a means to evade the normal liquidation requirements of $\S 337$.

70 See H.R. 4459, 86th Cong., 1st Sess. § 15 (1959).

71 The chapter $\mathrm{C}$ advisory recommendations were heard before the House Ways and Means Committee. See Hearings Before the House Ways and Means Committee, 86th Cong., Ist Sess. (1959). There was no debate, however, on the proposed amendment concerning the expansion of the liquidating trust device. 
Part of the uncertainty concerning the utility of liquidating trusts arises from the failure to distinguish between a trust whose sole purpose is to dispose of the remaining corporate property on behalf of the liquidating corporation's shareholders and a trust which does not dispose of its assets expeditiously but engages in continuing business ventures. Confusion in this area will be reduced when it is recognized that the trustee selected by the shareholders is not a continuation of the corporation but an entity whose tax status must be considered on its own characteristics. Thus, the important consideration for proper tax treatment is not the type of assets which are transferred to the trustee in dissolution but whether the trustee is conducting an active business or is simply exercising the power of selling the corporate assets and distributing the proceeds to the shareholders. 